DOI: $10.31891 / 2415-7929-2019-19-7$

УДК: $811.111 ' 373.23$ '42:791

NAZARENKO O., RUDENKO M.

Sumy State University

\title{
COGNITIVE ORIENTATION OF PROPER NAMES IN MODERN ENGLISH CINEMATIC DISCOURSE
}

The article is devoted to the question of proper names, the way of their creation and connection of the proper names with personal qualities, traits and character's lifestyle. The main focus is concentrated on links between proper names and characters' features in modern English cinematic discourse.

The development of modern English-language cinematic discourse has prompted many authors to pay attention to the question of the proper name as a nomination of the hero, a description of his character and lifestyle. The names have a significant meaning, the author expresses not only the actual reference of the character, but also his own attitude to him, gives a certain characteristic and key features of the hero, by which the viewer can make assumptions without even going into details. Names have an impact on the viewer, they have a connotative meaning, which is revealed through the character and details of the hero. The article gives examples of movies and series of the Marvel and DC universes with famous superheroes and thieves, whose names reflect not only the characteristics but also the hero's belonging to the good or evil side, his actions, behavior and psychological state, as well as superhuman abilities and characteristic. The article also considers examples of anthroponyms and names with a mythological basis, allusive proper names and simple short names. The tendencies of transferring figurative load to proper names are singled out in the work. Given symbolism of proper names in cinematic discourse makes the research relevant in modern linguistics. Further studying in this field as well as semantic analysis of the relationship between the name of the hero and his actions, characteristics, and the author's attitude to the character are promising in the long run.

Keywords: proper names, cinematic discourse, connotative meaning, anthroponyms, allusion

НАЗАРЕНКО О. В., РУДЕНКО М. Д. Сумський державний університет

\section{КОМУНІКАТИВНА СПРЯМОВАНІСТЬ ВЛАСНИХ ІМЕН В СУЧАСНОМУ АНГЛОМОВНОМУ КІНОДИСКУРСІ}

\begin{abstract}
У статті розглядаються питання формування власних імен та зв'язок між власним іменем та особистими якостями, рисами характеру та стилем життя героя. Основна увага приділяється взаємозв'язку власних імен з героями у сучасному англійському кінодискурсі.

Розвиток сучасного англомовного кінематичного дискурсу спонукав багатьох авторів звернути увагу на питання власного імені як номінації героя, опису його характеру та способу життя. Імена мають суттєе значення, автор висловлює не тільки фактичну посилання на персонажа, але і власне ставлення до нього, дає певну характеристику та ключові риси героя, за допомогою яких глядач може робити припущення, навіть не вдаючись у подробиці . Імена впливають на глядача, вони мають конотативне значення, яке розкривається через характер та деталі героя. У статті наводяться приклади фільмів та серіалів всесвітів Marvel та DC з відомими супергероями та злодіями, імена яких відображають не тільки характеристики, але також належність героя до доброї чи злої сторони, його дії, поведінку та психологічний стан, а також надлюдські здібності та характеристика. У статті також розглядаються приклади антропонімів та імен з міфологічною основою, алюзійних власних імен та простих коротких назв. У роботі виокремлено тенденції перенесення образного навантаження на власні імена. Враховуючи символіку власних імен у кінематографічному дискурсі, дослідження робить актуальним сучасну лінгвістику. Подальше вивчення в цій галузі, а також семантичний аналіз зв'язку між іменем героя та його діями, характеристиками та ставленням автора до персонажа є перспективними в довгостроковій перспективі.

Ключові слова: власні імена, кінодискурс, конотативне значення, антропоніми, алюзія.
\end{abstract}

Formulating the problem. The article is devoted to the topic of semantics of proper names, focusing on the modern English cinematic discourse. The question of polyaspects of proper names was discussed in works of such linguists as I. Kotova, I. Bilous, S. Spivac and others. Still the issue of proper names' functioning in cinematic discourse is open for the following investigations and demands special attention of researchers.

The object. The object of an article is a proper name. The subject of investigation is semantic content that was implicated in a proper name, recording information about a special character. Urgency of the topic is connected with a rapid development of modern cinematic discourse and linguists' growing interest to the semantic meaning of proper names is different types of modern discourse.

The main purpose. The main purpose of the article is to investigate cognitive orientation of proper names and their influence on the addressee.

Presenting the material. Among all types of discourse, cinematic discourse deserves special attention, because film art is perhaps the most influential art form in the modern world. Proper names are mandatory elements of cinematic discourse. Cinematic discourse is a semiotically complicated, dynamic process of interaction between the author and the film receptor, i.e. the process of interpretation of the film by the viewer and understanding of the content the movie contains $[1 ;$ p. 283]. Proper names are a special category in the lexical system of any language, they serve to denote objects or phenomena isolated from a certain type of persons, in other words, they are characterized by individual attachment to the denoted object [2, p. 34]. According to Cambridge Dictionary, a 
proper noun is the name of a particular person, place or object, spelled with a capital letter [3]. Unlike common names, generally proper names are devoid of connotations, they do not carry meaning in themselves, they can be determined only by referring to the real bearer of the name. They denote real objects, people or phenomena. The proper name contains a multilayered semantic and associative content, which was formed during the cultural and historical development of society [4, p. 1].

In cinematic discourse such proper names play the role of markers that indicate the type of activity, characteristics, a certain life position etc. Based on the presence of native speakers of certain associations (connotations) connected with particular proper names, the concept of encyclopedic meaning of proper names was formulated, i.e. their representation of knowledge that lies outside the language system [5, p. 251]. The name for the character should be chosen correctly, as the image of the hero and his features will be associated with this name in the viewer's imagination. In modern English-language cinematic discourse, great importance is attached to the names of the main characters, as one of the main tasks for authors is to make the viewer remember the characters, their traits, their activities, and so on. In superhero movies developed by Marvel or DC, there is a tendency to double the nomination of most heroes [6, p. 7]. This tendency indicates the duality of the images of the hero and the antihero, and it is the interaction between the personality and the corresponding role played by the hero that is revealed in the use of the double nomination. Each character has his or her real name, but then he or she receives a nickname based on his or her activities, lifestyle, special traits etc. Such movies or TV-shows get the title consonant with a main character's nickname (for example, DC's TV-show "Flash" was titled after main superhero Barry Allen, aka Flash). These films like their main characters have "speaking" names - the viewer can easily get the first impression about a character by just reading or hearing his nickname. A majority of such onyms are constructed with the help of the root "man" or "woman", denoting their "humanity" and belonging to "fighters for justice". The most popular heroes are Batwoman, Ironman, Spiderman, Superman etc. There are also examples of adding the word "doctor" for describing characters' occupation as scientists: "Doctor Alchemy" from "Flash", who was a lowly chemist with dissociative identity disorder.

The connotative meaning of the anthroponym contributes to the transfer of the author's attitude, giving reality to the situation, creating an atmosphere of ease and characterizes the bearer of the name. The connotation of extralinguistic origin comes from the properties of the object itself [7, p. 65]. Here we can illustrate it with an example of "Flash" character Killer Frost. She was a main protagonist during first seasons, but then her evil alterego appeared, being a total opposition to Caitlin Snow. In this situation we have two different characters as one human, and an evil side has the root Killer in her name, denoting being an antagonist. Furthermore, the creators show her future duality by giving her positive side the family name Snow, reflecting her future falling to the dark side. Without even watching a show one can note that this very character represents the evil team. From this TVshow we can provide another example of such a transferring. Professor Eobard Thawne was Flash's main enemy in the first season and during other seasons. His nickname was Reverse Flash, which means that he is opposite to Flash, and without watching the show the viewer can have the first impression of this character based on his nickname. Creators show his belonging to the antagonists of the TV-show and Barry Allen's enemies through his name.

Allusive proper name denotes a certain person and evokes a number of associations that refer the reader to the original image $[8$, p. 8]. If the author creates a bright character, then later while his mentioning in the minds of the audience there are features that are inherent in the character, remembered by the audience like appearance, actions, character traits, thoughts, a kind of conversation. The bright example of allusive proper name is Joker - a well-known DC antagonist and Batman's main enemy. Due to this mental state, the Joker is immune to fear. He perceives everything as a joke or a prank. His image and appearance is always associated with an evil clown with bright make-up. What is more, everything he does is perceived as a joke. In the movie "The Dark Knight” Joker's phrase "Why is so serious?" is considered to be a tagline, referring to Joker's attitude. For the audience the mention of Joker's name always evokes an association with "the one, who turns everything into a joke", but still the character appears to be a villain. Joker's prototype in a "Gotham", Jerome Valeska has once said about laugh: "There is nothing more contagious than laughter", which describes him as a clown that scares everybody around him and is considered to be mad. He was put to the asylum, where he was seeking for fun and show, sometimes even rude.

The main functions of anthroponyms are the function of artistic and figurative characteristics of a hero or other object of the name, as well as the function of transferring to the work historical and national color. In connection with the latter function, anthroponyms are one of the most important in the background knowledge of native speakers and culture, which is why to clearly understand the meaning of anthroponyms, the reader must have knowledge of the history of the country the hero is from. Here the brightest example is the hero of the Marvel's Captain America films got his name from belonging to a certain country, because the character was created as a patriot of his country, and during World War II he was portrayed as an active fighter against Hitler's coalition. Also we can name Natasha Romanoff, also known as Black Widow. Her belonging to another country is expressed through her Russian name; furthermore, it's the KGB who gave her the new nickname Black Widow.

With the help of the proper name the author tries not only to name a specific object, but also to report something about this object or to connect some additional information with the name in general, as well as to express feelings related to the object. Names of mythological and biblical origin are mythonymic formations used in the text of the work of art, recorded in the language, their content includes all the connotations that acquired the 
proper name during its functioning as a linguistic unit. When a movie creator uses names of mythological origin in a work, the context of the whole work influences the actualization of certain components of the meaning of one's own name, but all other components also remain in the viewer's mind, making the image marked by that name more voluminous and complete [9, p. 15]. The Marvel universe has examples like Thor or Loki. They were both named after Skandinavian gods: Thor is based on the image of the god of the same name from German-Scandinavian mythology, he was the god of thunder and lightning and his main power is to command lightning. Thor is able to summon lightning both from the heavens and emit them directly from the hammer Mjölnir. Loki is Thor's halfbrother, created on the basis of the Scandinavian god Loki. Loki is of Jotunheim descent. He possesses unique physical skills: enormous strength inherited from his ancestors, superhuman endurance, immunity to all known diseases and poisons. His Scandinavian prototype was the god of cunning and deceit, and a movie character was an experienced manipulator and schemer. Both characters have not only mythological-based names, but their stories and even superpowers were connected to the Scandinavian myths.

Another example of historical pattern in proper names is toponymics. The DC's main city is Gotham, gloomy metropolis, where the events described in "Batman" take place. Historically there was an English village named Gotham that was legendary because of the story of its citizens. They pretended to be mad in order not to let English king in. In "Batman" almost all characters are more or less insane, there is even an asylum called Arkham, where all survived criminals with mental disorders are kept. Metropolis, Superman's city is its antipode, depicted as a bright city. The name is consonant with common name metropolis, emphasizing its similarity to such big cities as New York, Chicago, Toronto etc. Almost all toponymics in DC Universe have the root "city" in their proper names: Central-City (Flash), Starling-City (The Arrow).

Other trends include the simplicity and prevalence of the names of the main characters in everyday life to emphasize that these characters are the same people as others. Every Marvel or DC character has his own real name, indicating that the character used to be a normal human. Later he receives his nickname based on his superpowers or activities. But if we consider first names, there is a tendency to make these names catchy and easy for readers to remember. The names all but consist of one or two syllables: Peter Parker, Bruce Wayne, Barry Allen and others. Each name is not only simple, but also popular - the name Peter Parker is the 57th in the ranking of the most popular English names for the last 100 years.

The metamorphic transfer created the name Hawkeye, the protagonist of the Marvel movie series. In the name of the semantic load reveals the hero's talent to shoot accurately, but also the hero is compared to a bird that has excellent eyesight. In addition to the talent to shoot a crossbow, Hawkeye has the skills to hit the target without error with any weapon due to sharp eyesight. Another example of metamorphic transfer is the character from "Gotham" The Penguin (real name is Oswald Cobblepot). He had his foot injured because of an accident, that's why he had a bit strange gait, like penguins do. What is more, he looked like a real penguin, that's why he got his nickname The Penguin. In this TV-show there was another character, Selina Kyle, who's known as Catwoman. She could climb buildings like a cat, and her clothing resembled a cat's appearance.

Conclusion. In conclusion, the proper name's main target is not only to nominate a character, but also to reflect his lifestyle, personal qualities and author's attitude toward this hero. Therefore, the main trends in the creation of one's proper name include the following: simplicity of the name, double nominations and a certain semantic load due to the transfer in the name of the characteristics of a hero by his type of activity, belonging to a particular state or personal characteristics.

Prospects for further research include a deeper study of the etymology and translation of proper names, semantic analysis of the relationship between the name of the hero and his actions.

\section{Література}

1. Полякова О.В. Дискурс анімаційного фільму як поле діяльності перекладача. Вісник ЛНУ ім. Тараса Шевченка. Вип. № 14 (273), Ч. І. Львів, 2013. С.282-286.

2. Білоус І.Л. Сучасні лінгвістичні погляди на Nomina Propria. Science and Education a New Dimension: Philology I(2). Issue: 11. Чернівці, 2013. С. 34-37.

3. Cambridge dictionary. URL : https://dictionary.cambridge.org/dictionary/english/proper-noun (дата звернення 20.09.20).

4 Співак С. М. Власна назва в композиційно-смисловій структурі віршованих текстів американської поезії: комунікативнокогнітивний підхід : автореф. дис... канд. філол. наук : 10.02.04. Київ, 2004. 19 с.

5. Зимовець Г.В. Семантичні особливості власних імен. Наукові записки. Серія “Філологічна”. Київ : Інститут мовознавства ім. О.О. Потебні НАНУ, 2010. С. 250-256.

6. Котова І.А. Антропоніми-номінації героя та антигероя в американському кінодискурсі. Одеський лінгвістичний вісник. Одеса, 2016. Вип. 7. С. 67-72.

7. Дмитренко В.А., Солощук Л.В. Коннотация антропонима в тексте анекдота. Функциональная лингвистика. Язык. Человек. Власть. Материальь конферениии. Ялта, 2001. С. 65-66.

8. Кудиба С.М. Функціональний потенціал алюзивних власних імен у рекламних текстах : автореф. дис... канд. філол. наук : 10.02.17. Львів : Львівський національний університет ім. Івана Франка, 2008. 25 с.

9. Павлюк Н.В. Власні назви міфологічного й біблійного походження та їх роль у поетонімогенезі : дис. канд. філол. наук : 10.02.15 / Донецький національний ун-т. Донецьк, 2006. 176 с.

\section{References}

1. Poljakova O.V. Dyskurs animacijnogho filjmu jak pole dijaljnosti perekladacha. Visnyk LNU im. Tarasa Shevchenka. Vyp. №14 (273), Ch. I. Ljviv, 2013. S.282-286. 
2. Bilous I.L. Suchasni linghvistychni poghljady na Nomina Propria. Chernivci : Science and Education a New Dimension: Philology, I(2), Issue: 11, 2013. C.34-37.

3. Cambridge dictionary. URL : https://dictionary.cambridge.org/dictionary/english/proper-noun (data zvernennja 20.09.20).

4. Spivak S. M. Vlasna nazva $\mathrm{v}$ kompozycijno-smyslovij strukturi virshovanykh tekstiv amerykansjkoji poeziji: komunikatyvnokoghnityvnyj pidkhid : avtoreferat. Kyjiv, 2004. $19 \mathrm{~s}$.

5. Zymovecj Gh.V. Semantychni osoblyvosti vlasnykh imen. Naukovi zapysky. Serija "Filologhichna". Kyjiv : Instytut movoznavstva im. O.O. Potebni NANU, 2010. S. 250-256.

6. Kotova I.A. Antroponimy-nominaciji gheroja ta antygheroja v amerykansjkomu kinodyskursi. Odesjkyj linghvistychnyj visnyk. Odesa, 2016. Vyp. 7. S. 67-72.

7. Dmytrenko V.A., Soloshhuk L.V. Konnotacyja antroponyma v tekste anekdota. Funkcyonaljnaja lynghvystyka. Jazblk. Chelovek. Vlastj. Materyali konferencyy. Jalta, 2001. S. 65-66.

8. Kudyba S.M. Funkcionaljnyj potencial aljuzyvnykh vlasnykh imen u reklamnykh tekstakh : avtoreferat. Ljviv : Ljvivsjkyj nacionaljnyj universytet im. Ivana Franka, 2008. 25 s.

9. Pavljuk N.V. Vlasni nazvy mifologhichnogho j biblijnogho pokhodzhennja ta jikh rolj u poetonimoghenezi : dys. kand. filol. nauk : 10.02.15 / Donecjkyj nacionaljnyj un-t. Donecjk, 2006. 176 s. 